\title{
A Problem Based Learning Framework to Assess and Develop Soft Skills in a Linear Programming Course
}

\section{Dr. Heriberto Garcia-Reyes, Tecnologico de Monterrey}

Heriberto Garcia is a Professor in the Industrial and Systems Engineering Department at the Tecnologico de Monterrey, Campus Monterrey. He received his B. Sc. on Mechanical Engineering and M. Sc. on Industrial Engineering degrees from the Tecnologico de Monterrey (Monterrey, Mexico). He is $\mathrm{PhD}$ in Industrial and Systems Engineering from Florida International University. Professor Garcia is coauthor of the book "Simulacion y analisis de sistemas con ProModel" published in Spanish; he has published papers related to teaching strategies, supply chain frameworks and educational challenges in several conference and journals.

\section{Cesia de la Garza Garza}

Cesia L. De-La-Garza-Garza is Teaching Assistant in the Industrial and Systems Engineering Department at the Tecnologico de Monterrey, Campus Monterrey. She received her B. Sc. on Industrial and Systems Engineering from the Tecnologico de Monterrey (Monterrey, Mexico). She has participated as Junior Consultant in projects related to productivity, process modeling, lean manufacturing implementations and strategic planning. She has presented several works in the Industrial and Systems Engineering Research Conference related to teaching strategies and the use of Problem-based Learning in engineering courses. 


\section{A Problem Based Learning Framework to Assess and Develop Soft Skills in a Linear Programming Course}

\section{Introduction}

Nowadays the industry require a new kind of engineer. Graduates should be able to deal with the challenge of globalization and the continuous advances in their professional field. Current students required acquiring skills on problem solving and communication, creativity and critical thinking, group management and leadership, besides of the traditional knowledge about mathematical modeling ${ }^{1}$. On the other hand, traditional mathematical courses commonly assume that the students learn concepts and theories, without the need of linking them to real problems. Empirical studies from several countries shown an important discrepancy between the skills developed in universities and those required by employers. In particular, these studies identified the lack of interpersonal and teamwork skills. The findings implies that the learning experiences

for students must be relevant, progressively more complex, and challenging ${ }^{2}$. Thus, current engineering students must be trained in the modelling of more complex problems, increase their abstraction capacity, and manage more powerful mathematical structures such that, they can solve a wide variety of engineering problems. Furthermore, students require developing skills to become self-directed and self-motivated in their activities associated with mathematical modeling and decision making ${ }^{3}$.

Commonly in the Industrial Engineering (IE) curricula, one of the first disciplinary courses that include mathematical modeling and decision making is the Linear Programming course (LP). This course usually have too many topics to be covered in a short span of time. Usually, a semester takes among thirteen to fifteen weeks. One of the instructor challenges is to decide the course scope whether the mathematical concepts behind the problem solution methods, the development of modeling skills, or the use of the model to support making decision processes. Moreover, the knowledge and skills developed in this course are required for other related courses such as goal programming, inventory management, scheduling and so forth. These factors open an opportunity to develop tools or methodologies oriented to use efficiently the lecturing time, such that the instructor can show all the benefits of the linear programming as modeling and decision making tool. Thus, due to the time constraint and the many challenges that this course implies, the inclusion of activities focused in the development of the student's skills looks like a titanic task.

One possible way to address this challenge is including new didactic techniques to improve the way the students get knowledge. One of these didactic techniques is the Problem-Based Learning (PBL) approach. PBL is a change from the traditional way to teaching where the main process of knowledge and discovery is focused in the learner rather than the teacher. In a PBL approach the 
Professor changes its role from an expert to a guide, advising and empowering the learners to take responsibility of the learning process ${ }^{4}$. The aim of a PBL assignment is to develop the student expertise about a topic through a collaborative work. According to this purpose problems use to be ill-structured, with dynamic contexts, and some missing or fuzzy information. Thus a PBL assignment offers an incentive for applying reasoning skills in order to understand the root of the problem and the possible alternatives to solve $i t^{5}$.

This work shows a framework to incorporate PBL as didactic technique in a linear programming course at Tecnologico de Monterrey. Thus the instructor can covering formulation, solution and sensitivity analysis through a set of problem based learning activities, resulting not only in the development of skills to use linear programming as modeling and decision making tool but providing an environment to improve the team work, the oral communication, citizenship and the self-learning in the participants.

This paper is organized as follows. The next section shows a literature review on Problem BasedLearning and frameworks in education. Section 3 describes the conceptual model used to integrate the framework. Section 4 discusses the proposed framework. Section 5 describes the framework validation process. Finally section 6 concludes with a summary of the research findings and future work.

\section{Literature Review}

Current trends in higher education make more complex the learning process for the learners and instructors. This complexity demands the commitment of the learners in a dynamic role in the knowledge acquisition process. Every learner is motivated to enter in proactive participation experience through a variety of processes, alternating from self-directed learning to group discussion, to peer teaching, to teacher guidance ${ }^{4}$. A useful way to understand and implement a complex process is the use of frameworks. The framework is used as roadmap of building blocks. Each building block is independent, allowing the reduction of the problem complexity. One of these building blocks found in education frameworks is the inclusion of active learning assignments such as Problem Based-Learning activities.

\subsection{Frameworks in Education}

Generally a framework provides a better understanding of a system's complexity, such that the partitioning and simplification of the system's elements can be studied through a modeling language and methodology common ${ }^{6}$. Frameworks in education are not new. They have been used for a wide variety of issues such as implementing total quality management in higher education programs ${ }^{7}$, incorporate social development into engineering studies ${ }^{8}$ or using PBL in leadership development ${ }^{9}$.

On the other hand, general frameworks have been used for the universities to improve their programs and operations. The main assumption is that the same framework used by an industry is adjustable for all kind of organization, including higher education institutions. An example is the Baldrige Education Criteria for Performance Excellence explored and adapted for some US universities in the 90's. The Criteria provides codified values and concepts of performance excellence from industry to education. Even though models developed outside education environments are widely accepted and has greater prestige with external stakeholders, they could 
be missing particular elements of the reality in higher education programs such as academic freedom ${ }^{10}$. Therefore, frameworks developed by educators could fill up the gap to modeling higher education institutions process.

In the literature there are several ways to represent a framework, for instance using a hierarchical diagram $^{7}$, using a diagram flow ${ }^{4}$ or using an acronym such as S.U.C.C.E.S.S.F.U.L. (Standardize systems concepts, Unify simulation concepts, Convey relationships among systems elements, Complement data collection and analysis concepts, Establish importance of modeling accuracy, Show modeling strategies, Select modeling software, Formulate with post processing analysis, Undertake model documentation activities, and Lead students through a comprehensive case study $)^{11}$. In education there are several examples such as a framework to adopt and implement blended courses in higher education ${ }^{12}$, a framework to implement total quality management in higher education programs ${ }^{7}$, or a framework to incorporate reality into engineering studies ${ }^{8}$.

Based on previous experiences, it could be said that, the more complex to use the framework is, the less it will be adopted. A useful framework is one that enables its users to achieve the goal for which was designed, in an easy way and in appropriate span of time; consequently, a good teaching framework must possess the following characteristics: Be easy to use and adopt, have a checklist of key elements to reach the goal, and provide guidelines to integrate their building blocks.

\subsection{Problem Based-Learning Origins and Benefits}

PBL began with medical school curricula, however, it has been used in a wider spectrum of disciplines including Architecture, Art, Business, Management, Engineering, Information Management, Law, Music, and Nursing among others ${ }^{4}$. PBL is a constructivist philosophy of teaching that creates an interactive learning environment encouraging students to work together, commonly in teams, to find solutions to problems. PBL is based on the principle that when students identify their own learning needs they are able to research, discuss, and analyze what has been discovered. Thus, through sharing concepts and interacting with the instructor and other classmates, the students learn effectively and deeply complex concepts to solve real problems ${ }^{13}$.

Even though PBL approaches have many forms; generally the learning environment is enhanced by a real-life problem. The main findings are collected, documented, shared and discussed in order to deal with the problem and solve it collaboratively ${ }^{14}$. According to Jennings ${ }^{15}$ as a result of the PBL experience, students can link theory to practice, deal with complexity of a particular situation, or improve judgment, expertise, and enliven teaching. PBL activities promoting the development of five important abilities in students: getting knowledge faster and value it, because it is used to solve real problems; awakens in them the importance of developing skills for solving real life problems; learn by themselves, since they require to find and evaluate information from several sources; explain complicated concepts in simple words, since they are obtaining meaningful through a real life problem definition; and work professionally in an interdisciplinary group in a collaborative way ${ }^{16}$. Previous works have demonstrated that students' insights of their learning experience are clearly related with the inclusion of PBL activities into the course. Students who received a problem-based course obtain higher scores than those who received a traditional course ${ }^{14}$. 
Commonly a PBL assignment includes the following steps ${ }^{5}$ :

a) A complex, real-world problem serve as trigger of the activity.

b) Instruction is conducted through cooperative learning. The instructor plays a role of facilitator instead of expert.

c) Participants identify, rethink, and analyze the problem in small teams.

d) Participants identify the unknown information that is required to solve the problem.

e) Participants generate possible alternatives to solve the problem based on research and data.

f) Participants in a collaborative process decide the better path to follow.

g) Participants present a proposal which is assessed by the instructor and other teams.

h) Participants ponder on the learning experience, improve their proposals and document the results.

Even though the benefits of include PBL activities in a course are widely documented, there are some drawbacks that should be considered. As all the pedagogical technique requires changes on the mindset of the students and instructors. These changes are not always adopted reducing the benefits of a PBL assignment ${ }^{4}$. On the other hand, the design of the PBL assignment could focus the student eyes only in to find the problem solution instead of the problem model and analysis, such that the students ignores opportunities for change and learning because they are looking for quick and fast solutions ${ }^{5}$. Although some of the practical and theoretical difficulties of including PBL activities in a course can be anticipated, much of the complexity will only disappear over time through experience as the new practice develops. Previous works attributed the success of this implementation to the systematic evaluation of instructors' learning needs, the support and confidence that coworkers gave each other, and creating a common culture among participants ${ }^{17}$.

\section{A Conceptual Model for a LP Course Including PBL}

Previous discussion remarks several challenges for the instructor of a LP course. An ambitious course program and a short span of time are two critical factors. Thus it is necessary to encourage students to take advantage of all the benefits of a PBL environment in order to accomplish the learning objectives of the course. On the other hand, a PBL environment is improved when it is used together with a virtual learning environment (VLE). A virtual learning environment is defined as the set of tools that aid the integration of Web-based materials into a web space called the electronic classroom. WebCT and Blackboard are two good examples of this $\mathrm{VLE}^{18}$. The linear programming course is supported by a Blackboard platform. Students use this space to interact and document their findings, agreements and to do list to solve the assigned PBL.

Similarly to the steps described in the literature review to solve a PBL, the participants follow the next steps for each PBL assigned during the course:

a) Read and understand the problem

b) Make a list of what they know and what they do not know

c) Make a problem statement

d) Make a list of what they need to know in order to solve the problem

e) Model and solve the problem

f) Provide recommendations and conclusions

g) Submit the final PBL report. 
The entire advance is recorded and exchanged through a Blackboard space of group interactions. In this group space the students receive feedback from their teammates and the instructor.

On the other hand, the instructor of a Linear Programming course usually teaches a method to solve a problem using mathematical models. Operations research books dedicate at least a section to describe the steps in the method considering that these steps apply too for the solution of a problem using LP. A sample of the methods found in the literature is shown in Table 1.

Table 1: Comparison among methods to solve problems using LP

\begin{tabular}{|c|c|c|c|}
\hline & Hillier and Liberman ${ }^{19}$ & Taha $^{20}$ & Winston $^{21}$ \\
\hline $\begin{array}{l}\text { Steps to } \\
\text { solve } \\
\text { problems } \\
\text { using } \\
\text { mathematical } \\
\text { models. }\end{array}$ & $\begin{array}{l}\text { 1. Define the problem } \\
\text { and gathering data } \\
\text { 2. Formulate a } \\
\text { mathematical model } \\
\text { 3. Develop a } \\
\text { computer-based } \\
\text { procedure to solve } \\
\text { the model } \\
\text { 4. Test the model and } \\
\text { improve it as needed } \\
\text { 5. Prepare for the } \\
\text { ongoing application } \\
\text { of the model } \\
\text { according to the } \\
\text { users requirements } \\
\text { 6. Implement the } \\
\text { actions suggested by } \\
\text { the model results }\end{array}$ & $\begin{array}{l}\text { 1. Define the problem } \\
\text { 2. Formulate the } \\
\text { model } \\
\text { 3. Solve the model } \\
\text { 4. Validate the model } \\
\text { 5. Implement the } \\
\text { solution }\end{array}$ & $\begin{array}{l}\text { 1. Formulate the } \\
\text { problem } \\
\text { 2. Observe the system } \\
\text { 3. Formulate a } \\
\text { mathematical model } \\
\text { of the problem } \\
\text { 4. Verify the model } \\
\text { and use the model } \\
\text { for prediction } \\
\text { 5. Select a suitable } \\
\text { alternative } \\
\text { 6. Present the results } \\
\text { and conclusions to } \\
\text { the organization } \\
\text { 7. Implement and } \\
\text { evaluate the } \\
\text { recommendation }\end{array}$ \\
\hline
\end{tabular}

Analyzing this table we can identify three main activities: Gathering Information, Formulate the problem mathematically, and analyze the results to implement changes. Thus the proposed method to solve a problem using linear programming is shown in Table 2:

Table 2: Method used to solve a problem using LP

\begin{tabular}{|c|c|c|}
\hline Gathering Information & Problem Modeling & $\begin{array}{l}\text { Results Analysis and } \\
\text { Documentation }\end{array}$ \\
\hline $\begin{array}{l}\text { 1. Understand the problem } \\
\text { 2. Identify the objective of } \\
\text { the problem } \\
\text { 3. Data Acquisition } \\
\text { 4. Gathering information } \\
\text { from data }\end{array}$ & $\begin{array}{l}\text { 5. Identify the decision } \\
\text { variables } \\
\text { 6. Identify constraints } \\
\text { 7. Formulate the problem } \\
\text { 8. Verify the model }\end{array}$ & $\begin{array}{l}\text { 9. Solve the model } \\
\text { 10. Validate de model } \\
\text { 11. Sensitivity analysis } \\
\text { 12. Results documentation }\end{array}$ \\
\hline
\end{tabular}

The last ingredient of the conceptual model for the framework is the learning environment. A mix of challenges and collaborative learning is provided by a set of PBL activities, such that the 
resulting environment encourages student-direct learning and problem-solving skills. Thus, students find themselves thrown into a creative environment in which they are active learners ${ }^{22}$.

Considering all the elements discussed in this section we defined a conceptual model to teach a linear programming course with the inclusion of PBL activities. There are three big columns supporting the model, collaboration; team work; and challenge. These columns are the foundation of the model and provide an environment of active learning, the appropriate environment to enhance a PBL experience. The model also contains three different learning scopes through the application of the method to solve a problem using a LP approach. These scopes are: gathering information, problem formulation, and results analysis including the model documentation and findings. Thus, the resulting conceptual model is shown in Figure 1.

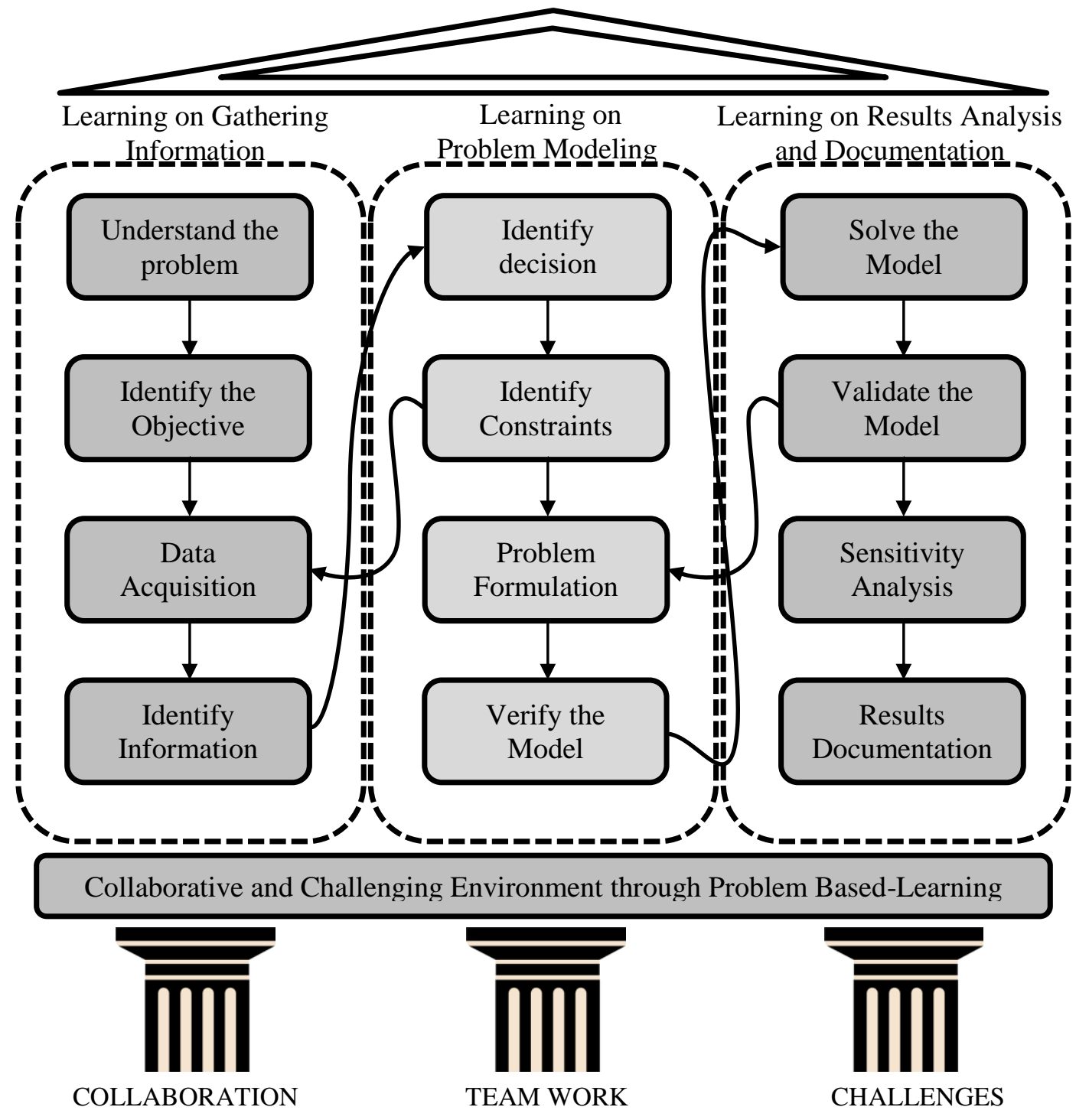

Figure 1: The conceptual model of a LP course including PBL activities

Once the conceptual model is defined the next step was to design the PBL activities so that each PBL enables the student to add new knowledge and solve more challenging problems, these 
activities should not be focused only in the use of LP as a solving problem tool but in the development of personal and professional skills such as leadership or citizenship. The following section shows the PBL objectives and the proposed framework.

\section{The Proposed Framework}

As the old Chinese proverb says, "I forget what I hear; I remember what I see; I learn what I do." A PBL experience provides an excellent environment to learn doing. This section describes the proposed framework and the elements considered to its construction and operation.

\subsection{The PBL sequence}

The LP course includes a sequence of PBL activities to incrementally increase the complexity of the problems to be solved and the expected learning results. Table 3 shows the objective of each PBL activity including the expected learning and the deliveries.

Table 3: Sequence of PBL activities

\begin{tabular}{|c|l|l|l|}
\hline PBL & \multicolumn{1}{|c|}{ Objective } & \multicolumn{1}{c|}{$\begin{array}{c}\text { Expected } \\
\text { Learning }\end{array}$} & \multicolumn{1}{c|}{ Deliveries } \\
\hline $\begin{array}{c}\text { Production } \\
\text { planning }\end{array}$ & $\begin{array}{l}\text { Introduce the PBL } \\
\text { challenge through } \\
\text { formulate a problem } \\
\text { and get the solution }\end{array}$ & $\begin{array}{l}\text { Modeling linear } \\
\text { problems using } \\
\text { spreadsheet to } \\
\text { obtain the solution }\end{array}$ & $\begin{array}{l}\text { A written report including the } \\
\text { model documentation and the } \\
\text { results }\end{array}$ \\
\hline $\begin{array}{c}\text { Product } \\
\text { distribution }\end{array}$ & $\begin{array}{l}\text { Use a specialized LP } \\
\text { software to solve the } \\
\text { model and analyze } \\
\text { the results }\end{array}$ & $\begin{array}{l}\text { Modeling linear } \\
\text { problems using } \\
\text { specialized } \\
\text { software to obtain } \\
\text { the solution }\end{array}$ & $\begin{array}{l}\text { A written report including the } \\
\text { model documentation and } \\
\text { analysis of the results } \\
\text { including the sensitivity } \\
\text { analysis }\end{array}$ \\
\hline 3 & $\begin{array}{l}\text { Perform a what-if } \\
\text { analysis when the } \\
\text { problem conditions } \\
\text { change dramatically }\end{array}$ & $\begin{array}{l}\text { Modeling linear } \\
\text { problems, get the } \\
\text { solution and } \\
\text { perform what-if } \\
\text { analysis }\end{array}$ & $\begin{array}{l}\text { Beside the previous, a } \\
\text { documentation of the method } \\
\text { or analysis performed to } \\
\text { suggest recommendations } \\
\text { and conclusion }\end{array}$ \\
\hline $\begin{array}{c}\text { Integer } \\
\text { programming }\end{array}$ & $\begin{array}{l}\text { Training on } \\
\text { information } \\
\text { gathering, self- } \\
\text { learning and oral } \\
\text { communication } \\
\text { through the } \\
\text { presentation of the }\end{array}$ & $\begin{array}{l}\text { Model, research } \\
\text { and solve integer } \\
\text { programming and }\end{array}$ & $\begin{array}{l}\text { network models } \\
\text { documentation, findings } \\
\text { presentation, a video } \\
\text { detailing the solution process } \\
\text { and conclusions, personal and } \\
\text { professional learning reached } \\
\text { by each team member }\end{array}$ \\
\hline
\end{tabular}

As is shown in the table, the first PBL is focused on developing modeling skills. The solution of this PBL should be obtained through the use of a spreadsheet program such as Excel. The PBL 
assignment is a production planning problem which includes over time, outsourcing and regular time. The delivery expected is a report of the problem results, team discussions and conclusions obtained, besides the documentation of the learning path followed in the PBL activity. The same process is replicated in the second PBL, which is a product distribution problem. In this assignment the solution should be obtained using a specialized software such as LINDO, MPL, WinQSB among others. The third PBL activity, a product mix problem, includes besides the objectives of the second PBL, a set of question such that the participants are oriented to perform a what-if analysis.

For all the PBL assignments the teams of students must to deliver a written report. This report is graded such that each team independently receives feedback about the results and conclusions obtained. Due to the time constraint all the teams require to schedule an appointment with the instructor to review the advance on the problem. In this appointment the instructor can detect common mistakes or misunderstanding of concepts, such that the instructor can feedback the entire class during the next lecture summarizing the opportunity areas, providing guide to solve the problem, and clarifying additional doubts or assumptions. This general feedback set the instructor expectations previously to the assignment of the next PBL activity. Figure 2 shows graphically the learning process applied for each PBL assignment.

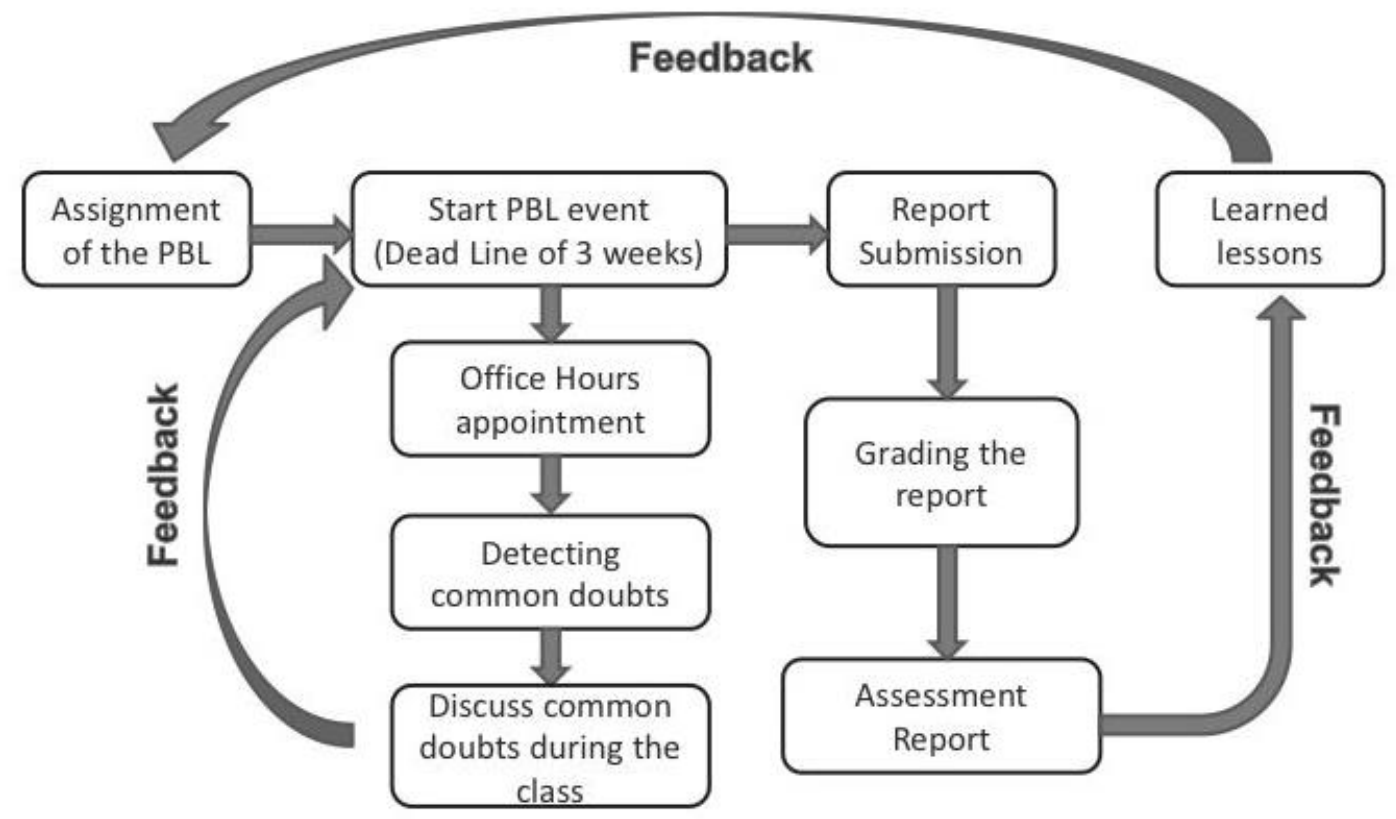

Figure 2: Learning process during each PBL assignment.

These PBL activities prepare the participants to deal with the last assignment. Now the students must to prepare an oral presentation during the lecturing time, generally during the last week of the course. The students must to investigate and prepare a presentation of a topic no explained by the instructor. In this case the topic is related to Integer Programming solution methods and solution of network problems such as transportation, assignment and transshipment. All teams have to make a comparison between the algorithms of a problem modeled using linear programming against other method such as branch and bound, cutting planes or the Voguel method depending on the problem assigned. 
During the last week of the course each team have twenty five minutes to describe the problem, explain the solution obtained, explain the new method researched and present a comparison of the benefits for each method. Additionally, each team has up to ten minutes to answer questions from their classmates and the instructor. During this presentation each team member must to participate explaining at least one question of the problem and answering a question from the class or the instructor. Thus each student will have the opportunity to use their oral skills and each team member needs to know deeply how the problem was solved. Finally the instructor make some comments regarding the problem solution, and the students' writing and oral skills observed during the presentations. After this feedback, each team have to improve their work and record a video with the final presentation of the PBL activity.

\subsection{Soft skills assessment}

Once the PBL sequence was defined, the next element of the framework is the representation of the personal and professional skills desired in the course. Even though, in the best case, soft skills are commonly associated with social or humanities courses, graduates from engineering programs requires to develop these skills. According to previous studies, soft skills could be the key to increase the employability in higher education graduates. The apparent graduates' weaknesses are in communication skills, team work and the attitude on how to carry themselves in the community (citizenship) among others ${ }^{23}$. Moreover, higher education programs are expected to prepare students for future professional work experience. In contrast students are expected to learn how to become exceptional professionals ready to handle any kind of challenge associated with his or her job instantaneously after graduation. Many times these two expectations are not well covered by universities programs, resulting in the mismatch between the competence of higher education graduates and the demands encountered in the workplace ${ }^{24}$.

Thus the proposed framework element intend to provide the space and opportunity to use the students' skills of leadership, the capacity to do research, writing reports, oral communications, and citizenship. The proposed element uses the $5 \mathrm{~W}+1 \mathrm{H}$ structure, an easy but common way to model the process. Additionally to the traditional $5 \mathrm{~W}+1 \mathrm{H}$ we include a new $\mathrm{W}$ remarking the relevance of the instructor role as facilitator, providing feedback, encouraging an interactive learning environment and promoting the collaborative work. Thus, the students reach a state of Wisdom which implies more than mastering of the competence an improvement on the students' skills. Other relevant point is the representation of the PBL assignments. The PBL activities 1, 2 and 3 are focused in the leadership, research and written communication skills. The last PBL includes oral communication and citizenship. The resulting representation provides a guide to the instructor to encourage the use of the soft skills through the PBL activities, such that these skills could be assessed and the students can have a feedback in order to improve those skills. Thus the Figure 3 shows this descriptions. 


\begin{tabular}{|c|c|c|c|c|c|}
\hline & \multicolumn{4}{|c|}{ PBL 1-2-3 } & \\
\hline & \multicolumn{5}{|c|}{ PBL 4} \\
\hline & Leadership & Research & $\begin{array}{c}\text { Written } \\
\text { Communication }\end{array}$ & $\begin{array}{c}\text { Oral } \\
\text { Communication }\end{array}$ & Citizenship \\
\hline What & $\begin{array}{l}\text { Leadership } \\
\text { skills and } \\
\text { values }\end{array}$ & $\begin{array}{l}\text { Information } \\
\text { required to } \\
\text { solve the } \\
\text { PBL }\end{array}$ & $\begin{array}{l}\text { Develop } \\
\text { abilities to } \\
\text { document the } \\
\text { model and } \\
\text { results }\end{array}$ & $\begin{array}{l}\text { Develop abilities } \\
\text { to convey } \\
\text { procedures, } \\
\text { assumptions and } \\
\text { results }\end{array}$ & $\begin{array}{l}\text { Awakening on } \\
\text { the use of LP } \\
\text { in the benefit } \\
\text { of the society }\end{array}$ \\
\hline Why & $\begin{array}{l}\text { Provide a } \\
\text { leadership } \\
\text { experience }\end{array}$ & $\begin{array}{l}\text { Motivate } \\
\text { the self- } \\
\text { learning } \\
\text { and } \\
\text { information } \\
\text { gathering }\end{array}$ & $\begin{array}{l}\text { Required skills } \\
\text { asked by } \\
\text { employers }\end{array}$ & $\begin{array}{l}\text { Required skills } \\
\text { asked by } \\
\text { employers }\end{array}$ & $\begin{array}{l}\text { Notice the } \\
\text { impact of the } \\
\text { profession in } \\
\text { the common } \\
\text { well }\end{array}$ \\
\hline Who & $\begin{array}{l}\text { Leader in } \\
\text { turn }\end{array}$ & $\begin{array}{c}\text { All the } \\
\text { students }\end{array}$ & $\begin{array}{c}\text { Each Team } \\
\text { member }\end{array}$ & Student & Everyone \\
\hline When & $\begin{array}{l}\text { During the } \\
\text { solution } \\
\text { time for a } \\
\text { PBL }\end{array}$ & $\begin{array}{l}\text { During the } \\
\text { solution } \\
\text { time for a } \\
\text { PBL }\end{array}$ & $\begin{array}{l}\text { During the } \\
\text { report writing }\end{array}$ & $\begin{array}{l}\text { Last week of the } \\
\text { course }\end{array}$ & $\begin{array}{l}\text { Last week of } \\
\text { the course }\end{array}$ \\
\hline Where & $\begin{array}{c}\text { Team } \\
\text { Meetings }\end{array}$ & $\begin{array}{l}\text { Library, } \\
\text { Web } \\
\text { Resources, } \\
\text { Journals } \\
\text { and } \\
\text { Databases }\end{array}$ & Team Meetings & Classroom & $\begin{array}{c}\text { Classroom and } \\
\text { VLE }\end{array}$ \\
\hline How & $\begin{array}{l}\text { Ensuring } \\
\text { turning } \\
\text { leadership } \\
\text { and } \\
\text { providing } \\
\text { feedback to } \\
\text { the leader } \\
\text { in turn }\end{array}$ & $\begin{array}{l}\text { Including } \\
\text { new } \\
\text { Concepts in } \\
\text { each PBL }\end{array}$ & $\begin{array}{l}\text { Assigning a } \\
\text { grade and } \\
\text { assessing the } \\
\text { written quality } \\
\text { of the report }\end{array}$ & $\begin{array}{l}\text { Assigning a grade } \\
\text { and assessing the } \\
\text { quality of the } \\
\text { presentation and } \\
\text { their answers } \\
\text { during the time for } \\
\text { questions }\end{array}$ & $\begin{array}{c}\text { Write and } \\
\text { share a wiki } \\
\text { about the use } \\
\text { of LP in the } \\
\text { development } \\
\text { of the society. } \\
\text { Afterwards } \\
\text { write an } \\
\text { individual } \\
\text { essay } \\
\text { including main } \\
\text { thoughts and } \\
\text { conclusions }\end{array}$ \\
\hline $\begin{array}{l}\text { Wisdom } \\
\text { (Learning) }\end{array}$ & & Feedback & Instructor, te & nates and classmates & \\
\hline
\end{tabular}

Figure 3: Framework to incorporate personal and professional skills in a LP course.

4.3 Grading the PBL activities

Regarding the students grading the PBL activities are part of the grading policy. Many times a PBL could have an important weight in the final grade of the student. However, this scope may 
reward students with a low performance in the course which are covered by a good teamwork. Thus, after several iterations the grade policy of this course is as follows:

$\begin{array}{lc}3 \text { partial exams } & 40 \% \\ 1 \text { final exam } & 20 \% \\ \text { PBL activities } & 10 \% \\ \text { Final PBL } & 10 \% \\ \text { Homework } & 15 \% \\ \text { Self and peer assessment } & 5 \%\end{array}$

Reviewing the grade scale, the PBL activities implies only the twenty percent of the final grade of a student. Additionally, all the students must to complete a peer assessment about the teammates' soft skills. The assessment include eight question. At each question, the student should to grade the teammates' performance in a scale from 6 to 10 . Where 6 implies a bad performance and 10 an excellent grade. The questions assess leadership, teamwork, collaboration, proactivity and participation in the problem solution and writing report activities. The average grade obtained by each student multiply the average grade of the PBL assignment such that a student which obtain as average 90 in the PBL activity and $80 \%$ in the peer assessment implies a final grade of 72 .

Regarding the initial three PBL activities the grading procedure implies an $80 \%$ assigned to the problem results, $10 \%$ to the writing report, $5 \%$ to the report presentation and $5 \%$ to the problem analysis. On the other hand, the final PBL is graded in a different way due to the oral presentation. The following rubric is applied to feedback the students and integrates their grades.

Table 4: Rubric to assess the oral presentation

\begin{tabular}{|l|l|l|}
\hline \multicolumn{1}{|c|}{ Concept } & Points (1 to 5) & Comments \\
\hline Understanding of the problem & & \\
\hline Content quality & & \\
\hline Presentation Quality & & \\
\hline Oral communication & & \\
\hline Result analysis & & \\
\hline
\end{tabular}

1. Poor, 2. Inconsistent, 3. Acceptable, 4. Good, and 5 Excellent

\section{Results}

The results obtained by the application of the framework in the LP course are reported in several sections: students' feedback, faculty capitalization and course improvement.

\subsection{Students' feedback}

Once the course is completed the students are invited to answer a survey about the benefits of participating in a course with a PBL environment. The survey uses a Likert scale from strongly agree to strongly disagree. Due to the Likert scale only provides numerical answers we also included a question about the reason of the given answer. Thus, the results are expected to show not only the students' assessment but the reasons used by them to give a particular grade. This survey was applied to the students of one LP course during the spring and fall semester of 2011, 2012 and 2013. A total of 237 student students participate in these courses. From this population 
of students, 153 of them answer the survey. The results obtained are shown in Table 4. Notice that none of them selected the option disagree or strongly disagree.

Table 5: Results of the Likert Scale questions.

\begin{tabular}{|l|c|c|c|}
\hline \multicolumn{1}{|c|}{ Question } & $\begin{array}{c}\text { Strongly } \\
\text { Agree }\end{array}$ & Agree & Indifferent \\
\hline $\begin{array}{l}\text { Do I believe that, with the PBL environment of the } \\
\text { course, I better understand the possible applications of } \\
\text { linear programming in the industry? }\end{array}$ & $67 \%$ & $32 \%$ & $1 \%$ \\
\hline $\begin{array}{l}\text { Do I believe that the PBL environment of the course } \\
\text { promotes the learning of specialized software to solve } \\
\text { linear programming models? }\end{array}$ & $69 \%$ & $29 \%$ & $2 \%$ \\
\hline $\begin{array}{l}\text { Do I believe that my modeling skills using linear } \\
\text { programming problems were improved after the PBL } \\
\text { experience? }\end{array}$ & $62 \%$ & $33 \%$ & $5 \%$ \\
\hline $\begin{array}{l}\text { Do I believe that my skills for self-learning methods to } \\
\text { solve linear programming problems were improved } \\
\text { after the PBL experience? }\end{array}$ & $52 \%$ & $40 \%$ & $8 \%$ \\
\hline $\begin{array}{l}\text { Do I believe that my knowledge about how perform a } \\
\text { What-if analysis was improved after the PBL } \\
\text { experience? }\end{array}$ & $61 \%$ & $33 \%$ & $6 \%$ \\
\hline
\end{tabular}

As is shown in Table 4 most of the answers are at least "agreed" in each question. The biggest perception of agreement is related to the learning of software to solve linear programming models. On the other hand, the biggest percentage of indifference was obtained in the selflearning methods to solve a topic uncovered by the instructor. These fourth question opens a room for reflection about how to reduce these perception results. All the answers were summarized and grouped using a relationship diagram. In order to remark the findings we only show the reasons which represents close to the $80 \%$ of the results.

Table 6: Most relevant reason for each question

\begin{tabular}{|c|l|c|}
\hline Question & \multicolumn{1}{|c|}{ Results } & Percentage \\
\hline \multirow{2}{*}{1} & Enable the solution of the other course assignments & 43 \\
\cline { 2 - 3 } & Shows that students are able to solve real-life problems & 37 \\
\hline \multirow{2}{*}{2} & Encourage the reading of tutorials and on line help systems & 40 \\
\cline { 2 - 3 } & Shows the necessity of use a software to solve real-life problems & 38 \\
\hline \multirow{4}{*}{3} & Helps to understand the topics covered in the course & 26 \\
\cline { 2 - 3 } & Solve a difficult problem makes easy to solve didactic problems & 21 \\
\cline { 2 - 3 } & $\begin{array}{l}\text { Using software to verify the problem solution allows to identify } \\
\text { modeling mistakes }\end{array}$ & 29 \\
\hline \multirow{4}{*}{4} & Development of trust to solve real problems without help & 25 \\
\cline { 2 - 3 } & Provides experience and your skill are increased & 23 \\
\cline { 2 - 3 } & $\begin{array}{l}\text { Promotes a self-learning environment using several tools such as } \\
\text { internet, journals etc. }\end{array}$ & 45 \\
\hline \multirow{2}{*}{5} & Increase the skill related to decision making & 52 \\
\cline { 2 - 3 } & Analyzing scenarios allows to understand the problem deeply & 29 \\
\hline
\end{tabular}


Most of the results show positive answers regarding the expected benefits of a PBL environment offering directions to improve the learning process in the course. Regarding the personal and professional skills, they are more difficult to measure. In order to get feedback about the benefit of the proposed framework, students interact in blogs in the VLE, afterwards they write an essay about their experience in the course and the possible social benefits that the solution of a problem using LP can provide. Particularly the citizenship element is remarked in most of the essays, the students do not expect found applications of LP in social problems. Most common applications of a LP model includes production planning, product distribution, product mix or work balancing for workers and employees. However the students do not imagine application on the efficient use of some resource such that the pollution is reduce, the best way to feed students applied for the Chilean Government or the use of a LP approach to design a forest renewal and conservation. The consensus of the student in all the courses was that they have the opportunity to learn about how their profession can improve not only the profit of an enterprise but the life style of those who less have.

Regarding the students' grades, previous three years to the implementation of the framework the average percentage of the students who fails the course was $12.5 \%$ while after the implementation (2011 to 2013) was $2.3 \%$ implying a benefit of 10 percentage points. As was previously discussed the weight of the PBL assignments is $20 \%$ of the final grade. This percentage was the same previous to the 2011, the main difference was the use of the framework to design the goals of each PBL and the use of the rubrics. Due to the peer assessment activity, the possibility that a student pass the course rewarded by the teamwork assignment is limited but it is possible if the teammates do not complete this peer assessment ethically. Thus, the instructor takes some minutes previously to the peer assessment activity to talk about the ethical responsibility of this assessment.

\subsection{Faculty capitalization}

Even though there are some answers in the student survey which imply possible improvements in the course, they represent a small percentage providing an opportunity to review the teaching method; the time spent in the PBL solution; and how to deal with personal cases such as a team leader uses an authoritarian position to solve differences among the team members.

As a part of the institutional course assessment the department of academic development applies an anonymous survey to all the students. The following table shows the results obtained for this LP course. The scale is from 1 to 5 were 1 is the best and 5 is the worst.

\begin{tabular}{|l|c|c|c|c|}
\hline \multicolumn{1}{|c|}{ Semester } & Sections & Average & Course assessment & Rank \\
\hline Spring 2011 & 5 & 1.7 & 1.17 & $1 / 5$ \\
\hline Fall 2011 & 5 & 1.47 & 1.27 & $1 / 5$ \\
\hline Spring 2012 & 5 & 1.38 & 1.32 & $1 / 5$ \\
\hline Fall 2012 & 5 & 1.49 & 1.45 & $2 / 5$ \\
\hline Spring 2013 & 5 & 1.24 & 1.14 & $2 / 5$ \\
\hline Fall 2013 & 5 & 1.45 & 1.4 & $2 / 5$ \\
\hline
\end{tabular}

This is an overall assessment of the course. In all the semesters the course is positioned in the rank one or two among all the course sections. These results support the hypothesis that the 
framework is adding value to the course. However, we must to remark the amount of time and work required to operate the course. Moreover, we must to change the PBL assignment each year due to the possibility of use the same information generated by other team in a previous semester. Also, we detect some students which were not attracted by the PBL environment. Most of the times this students were asking the traditional lecturing method. The solution to these students was motivate them to attend office hours to clarify doubts and concepts.

\subsection{Course improvements}

One of the benefits of this experience was found some students which really appreciate the effort to go further of a disciplinary course. Even though the rubric of the final PBL commonly reported values of 2 or 3 . The teams presenting at the end include in their presentation many recommendations given to the teams which present their work previously. Nowadays, this course is passing through a change to include a hybrid format and gamification in some activities.

\section{Conclusions and Future Works}

A linear programming course presents several challenges to prepare the new engineers for a globalized world. PBL is a great tool to promote an environment which allows increasing the skills of modeling, decision making and understanding of a real problem.

In spite of a traditional linear programming course have a short span of time to cover many topics, a PBL approach allows to increase the teaching efficiency such that these topics are covered and opens space to promote research and self-learning.

The PBL environment designed for the linear programming course have some opportunity areas but, in a general sense, the results shown that is close to impact all the participants in a positive way, developing modeling skills, interactive learning and self-confidence to making decisions using the results provide for a mathematical model. Also, the course format allows to open opportunities to assess and improve soft skills such as communication skills, team work, leadership and citizenship.

Even though this research found very useful the use of PBL environment, it is important to remark the time required to prepare, design and manage the course is greater than the time required by a traditional course. This fact should be considered in order to avoid over charge students and instructors with many PBL activities in the same semester. Any research related to find this balance will be an interesting future work.

\section{References}

1. R. A. Tarmizi, M. A. A. Tarmizi, N. I. Loginin and M. Z. Mokhtar, Problem-based learning: engaging students in acquisition of mathematical competency, Procedia Social and Behavioral Sciences, 2, 2010, pp. 4683-4688.

2. D. Bamford, K. Karjalainen and E. Jenavs, An evaluation of problem-based assessment in teaching operations management, International Journal of Operations \& Production Management, 12(32), 2012, pp. 1493 - 1514.

3. R. A. Tarmizi and S. Bayat, Effects of problem-based learning approach in learning of statistics among university students, Procedia Social and Behavioral Sciences, 8, 2010, pp. 384-392. 
4. R. K. Yeo, Problem-based learning: lessons for administrators, educators and learners, International Journal of Educational Management, 19(7), 2005, pp. 541-551.

5. C. Schechter, Switching cognitive gears Problem-based learning and success-based learning as instructional frameworks in leadership education, Journal of Educational Administration, 49(2), 2011, pp. 143-165.

6. K. Kosanke and M. Zelm, CIMOSA Modelling Process, Computers in Industry, 40, 1999, pp. 141-153.

7. S. Venkatraman, A framework for implementing TQM in higher education programs, Quality Assurance in Education, 1(15), 2007, pp. $92-112$.

8. A. Pérez-Foguet, S. Oliete-Josa and A. Saz-Carranza, Development education and engineering: A framework for incorporating reality of developing countries into engineering studies, International Journal of Sustainability in Higher Education, 3(6), 2005, pp. 278 - 303.

9. R. K. Yeo, Problem-based learning: a viable approach in leadership development?, Journal of Management Development, 9(26), 2007, pp. $874-894$.

10. D. Houston, Rethinking quality and improvement in higher education, Quality Assurance in Education, 1(16), 2008, pp. $61-79$.

11. H. Garcia and M. A. Centeno, S.u.c.c.e.s.s.f.u.l.: A framework for designing discrete event simulation courses, Proceedings of the Winter Simulation Conference, Austin Texas, December 13-16, 2009, pp. 289-298.

12. Ch. R. Graham, W. Woodfield, and J. Buckley-Harrison, A framework for institutional adoption and implementation of blended learning in higher education, Internet and Higher Education, 18, 2013, pp. 4-14.

13. G. W. Roberts, Advancing new approaches to learning and teaching- Introducing appreciative inquiry to a Problem-Based Learning Curriculum, Journal of Applied Research in Higher Education, 2(1), 2010, pp. 16-24.

14. K. Downing, F. Ning and K. Shin, Impact of problem-based learning on student experience and metacognitive development, Multicultural Education \& Technology Journal, 5(1), 2011, pp. 55-69.

15. D. Jennings, Strategic Management: an evaluation of the use of three learning methods, Journal of Management Development, 21(9/10), 2002, pp. 655-665.

16. I. Thomas, Critical Thinking, Transformative Learning, Sustainable Education and Problem-Based Learning in Universities, Journal of Transformative Education, 7(3), 2010, pp. 245 - 264.

17. R. Spronken-Smith and T. Harland, Learning to teach with problem-based learning, Active Learning in Higher Education, 2(10), 2009, pp. 138 - 153.

18. K. Saumure and A. Shiri, Integrating digital libraries and virtual learning environments, Library Review, 55(8), 2006, pp. 474-488.

19. F. S. Hillier and G. J. Liberman, G. J., 2010, Introduction to Operation Research, $9^{\text {th }}$ Edition, McGraw Hill, New York, 2010.

20. H. Taha, Operations Research: An Introduction, Prentice Hall, New Jersey, 2011.

21. W. Winston, Operation Research: Applications and Algorithms, $4^{\text {th }}$ Edition, Cengage, Canada, 2004.

22. N. L. Maxwell, J. R. Mergendoller and Y. Bellisimo, Y., Developing a problem-based learning simulation: An economics unit on trade, Simulation \& Gaming, 4(35), 2004, pp. 488 - 498.

23. A. Esa, A. Selamat, S. Padil, and J. Jamaludin, Applications Of Soft Skills In Engineering Programme At Polytechnic Malaysia, Social and Behavioral Sciences, 140, 2014, pp. 115 - 120.

24. S. Nilsson, "Enhancing individual employability: the perspective of engineering graduates", Education + Training, 2 (6/7), 2014, pp. 540 - 551 